\title{
Oorzaken en Gevolgen in de Kaapse Geschiedenis ten Tijde van de Compagnie.
}

\author{
Deur Prof. dr. H. SMITSKAMP.

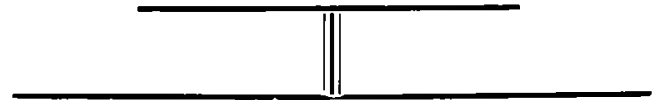 \\ TEGEN wil en dank, tegen alle bewuste opzet in, \\ als ongewild resultaat van een beleid, waaraan \\ geheel andere motieven ten grondslag lagen, is uit \\ de geringe volksplanting een zelfstandige, levens- \\ krachtige natie gegroeid.
}

„Stichter tegen wil en dank": zo is Jan van Riebeeck door zijn biograaf getypeerd. Uit zijn werk aan de Kaap is iets volkomen anders voortgekomen, dan hij, in overeenstemming met zijn lastgevers, met de vestiging van de nederzetting had bedoeld. De kolonie werd een vaderland, de herberg een tehuis.

Wanneer we, bij de herdenking van de man die aan het begin staat van deze ontwikkeling, ons opnieuw verdiepen in de lotgevallen van de Nederlandse stam in Zuid-Afrika, blijkt dezelfde karakteristiek, die van de stichter werd gegeven, ook voor de stichting bruikbaar. Tegen wil en dank, tegen alle bewuste opzet in, als ongewild resultaat van een beleid, waaraan geheel andere motieven ten grondslag lagen, is uit de geringe volksplanting een zelfstandige, levenskrachtige natie gegroeid.

Hoe weining stoort de gang der geschiedenis zich vaak aan menselijke bedoelingen! Tussen hun oogmerk en de daadwerkelijke uitkomst kan de discrepantie zo groot zijn, dat zelfs achteraf een sluitende causale verklaring onmogelijk is. Men spreekt dan van kleine oorzaken en grote gevolgen, van toevallige omstandigheden, of, op Hegeliaanse trant, van de „List der Vernunft”, die dwars door de daden van kortzichtige mensen heen de loop van het gebeuren bepaalt. Laten we ons liever houden aan de oude Hollandse sinspreuk, door de Bijbel ingegeven, dat de mens wikt, maar God beschikt.

Wel zeer duidelijk blijkt dat uit de geschiedenis van de nederzetting ijdens de eerste anderhalve eeuw van haar bestaan. De Mist heeft het 
terstond na afloop van die periode, in zijn memorie van 1802, reeds voortreffelijk onder woorden gebracht: „Den Caabschen Uithoek, dan oorspronkelijk alleen tot eene ververschingsplaats bestemd, is, bij toeval, ongevoelig en misschien tegen den wensch, maar zeker tegen de gedachten der eerste oprichters, in eene aanzienlijke landbouwende Colonie veranderd." 1)

Bij enkele bekende, maar altijd weer gedenkwaardige momenten van dit ongedacht verloop willen wij een ogenblik stilstaan.

Opmerkelijk is al terstond, dat het in de eeuw, die de Nederlanders zag uitzwermen naar drie werelddelen, nergens tot een blijvende volksplanting is gekomen dan aan de Zuidpunt van Afrika. De oorzaken van dit falen zijn bekend genoeg. De Compagnie was nu eenmaal een handelslichaam, dat zijn politiek regelde naar het doel, waartoe het was opgericht: het behalen van zo hoog mogelijke dividenden op korte termijn. Daarom was aan Coen's kolonisatieplannen voor Indië geen uitvoering gegeven, want het monopoliestelsel had voor vrijburgers geen ruimte. Om de kosten had ook de Westindische Compagnie de ontluikende nederzetting in Noord-Amerika laten verkommeren, zodat zij aan de Engelsen ten prooi viel, en Brazilië na een halfhartige poging opgegeven.

Zo zijn kansen gemist, die nimmer terugkeerden. Wij kunnen het achteraf betreuren, maar een billijk oordeel moet ook de keerzij van de medaille in acht nemen. Dat Engeland in Noord-Amerika wél succes heeft gehad met de volksplanting, had ten dele een minder fraaie oorzaak: een kerkelijk régime, dat dissenters tot emigratie dreef, kende de Republiek der Verenigde Nederlanden niet.

Een „verzuimd Zuid-Afrika" is het niet geworden, maar ook dat is waarlijk niet te danken geweest aan het inzicht, dat er voor Nederlandse volkskracht een toekomst lag aan de Kaap. Al wat tot dit welslagen heeft meegewerkt, is uit geheel andere motieven verricht.

Van Riebeeck zelf heeft al spoedig ingezien, dat het verversingstation om economisch rendabel te zijn kolonisten nodig had. Zo weinig dacht hij daarbij aan "stambelangen,"-mag men dat trouwens van een 17de-eeuwer verwachten?-, dat hij de oplossing aanvankelijk zocht in de invoer van „eene menigte Chinezen of andere laboreuse menschen of huisgezinnen."2) Toen Heren XVII zijn denkbeeld overnamen, en be-

1) Zie J. P. van der Merwe. Die Kaap onder die Bataafse Republiek. 1803. 1806 (1926), bls. 78v.

2) Dagboek 29 April 1652. 
sloten was tot kolonisatie op zeer bescheiden schaal, niet door uitheemse, maar door Hollandse vrijburgers, heeft van Riebeeck zeer juist bezeft, op welke voorwaarde er alleen kans van slagen bestond: men moest de mensen voor jaren lang binden aan de grond, want slechts dan zouden zij wellicht ,mettertijd heel van Hollant afwennen ende enemael van dese plaetse haar vaderlant mogen maecken." 3) Een met het oog op de toekomstige ontwikkeling gezonde gedachte, maar die weinig strookte met de bedoeling van de Hoge Regering, welke eigenlijk nooit is afgestapt van de eerste opzet, ,een beknopte residentie aen de Caap te houden." 4)

Wat echter Van Riebeeck deze raad ingaf, was wederom in de voornaamste plaats de zorg voor de continuïteit in de voedselvoorziening ten bate van de passerende Indië-vaarders, en niet de begeerte, aan de Kaap een nieuw Nederland te doen verrijzen. Zijn eigen verblijf aldaar betekende voor hemzelf trouwens ook niet meer dan een liefst zo kort mogelijke stage, om in Indië tot hoger ambten op te klimmen. Hij heeft zijn werk plichtsgetrouw en goed gedaan, had er ook hart voor, maar hij was nu eenmaal een man van de tweede of derde generatie van kolonisators. Noch hij, noch zijn superieuren leefden meer met dezelfde bewustheid uit de innige samengang van handelsgeest, vaderlandsliefde en religie, die de besten van het eerste geslacht, een de Moucheron, een J. P. Coen gekenmerkt had, kooplui van groot formaat, maar wier diepste aandrift gelegen had in de begeerte, de macht van het Gemenebest te vergroten, omdat zij dit beschouwden als een verkoren instrument tot de strijd voor Gods eer. Geheel afwezig is die gezindheid ook bij de lateren niet, maar men ontkomt niet aan de indruk, dat zij dan meer een zaak van traditie dan van bezieling is geworden, nog wel op de achtergrond werkzaam, maar niet meer de primaire beweegkracht. Wanneer van Riebeeck in zijn "Nader Consideratie” van 1651 spreekt van „de voortplantinge onzer gereformeerde Christelijcke religie" 5) als een der te verwachten vruchten van een vestiging aan de Kaap, heeft hij dat ongetwijfeld oprecht gemeend, maar de vraag is gewettigd, of we hier alleen te maken hebben met een argument te meer, dan wel met het overheersend motief. Het materieel belang is gaan overwegen als prikkel van de ondernemingslust, en de geestelijke winst, de godsdienstige zo goed als de nationale, krijgt het karakter van een toevallige bate, op de „koop" toe verworven.

3) E. C. Godeje Molsbergen. De stichter van Hollands Zuid-Afrika, Jan van Riebeeck (1912), blz. 109.

4) t.a.p., blz. 159 .

5) t.a.p., blz. 220 . 
Ik denk in dit verband in het bijzonder aan een vraagstuk, dat voor de toekomst van Zuid-Afrika, met het oog op de waarborging van het Nederlands karakter der samenleving, van het allergrootste gewicht is geweest, nl. de zorg voor de moedertaal. Het zou een miskenning van het onderscheid der tijden zijn, indien men in dit opzicht de Compagnie een verwijt makte van het ontbreken van een doelbewust op nationale overwegingen gebaseerd beleid. Zelfs al hadden deze laatsten haar politiek in het algemeen bepaald,--hetgeen niet het geval is-, dan nog zou zij uit dien hoofde aan de taalkwestie vermoedelijk weinig aandacht hebben geschonken. In de $17 \mathrm{de}$ eeuw vormde taalgemeenschap ten hoogste een secundair kenmerk van nationaliteit; pas in de 19de, de eeuw van het nationalisme, is zij gaan gelden als een natie-scheppende factor bij uitstek. Over het geheel werd trouwens in vroeger tijd aan het nationale op zichzelf nog niet de absolute waarde toegekend, die het later heeft verkregen. Als het er op aankwam, trokken andere banden sterker dan die van het behoren tot één volk.

Maar ook hier kunnen we weer het merkwaardige verschijnsel constateren dat maatregelen, om andere redenen genomen, onbedoeld het gevolg hebben gehad van de bewaring van de Nederlandse cultuur aan de Kaap. Waarom kreeg van Riebeeck van de Gouverneur-Generaal van Goens de instructie, in het verkeer met de uit de Oost geïmporteerde slaven geen Portugees te spreken, maar uitsluitend de moedertaal te gebruiken? 6) Daaraan lag toch wel vóór alles de wens ten grondslag, om administratie en handel de moeilijkheid te besparen, die men in Indië niet had kunnen vermijden, $\mathrm{nl}$. dat in de omgang met de inheemsen veelal het vreemde Portugees tot voertaal diende. Uit practische overwegingen was een linguistisch homogene bevolking wenselijk. Terwijl men tegen bloedmenging, in de vorm van huwelijken tussen Compagnies-dienaren met vrije, gekerstende Indische vrouwen geen bezwaar maakte, was men voor taalmenging op zijn hoede.

Dat daarbij ook andere dan alleen administratieve redenen in het spel kwamen, bleek bij de inkomst van Hugenoten en Waldensen op het einde van de eeuw. Toen dreigde het gevaar, niet van verdwijning of verbastering van het Hollands, maar van tweetaligheid. De nieuwe nederzetters vormden immers een belangrijk percentage van de blanke bevolking. Met hun taal zouden zij allicht ook hun nationale eigenaardigheid hebben gehandhaafd. En hoe groot de zuigkracht van de Franse beschaving, juist in die tijd, op de Nederlandse geweest is, is be-

6) t.a.p., blz. 103 . 
kend genoeg. Opnieuw werd toen van hogerhand ingegrepen, maar ook nu weer zonder dat er sprake was van bewuste bescherming der vaderlandse cultuur, al kwam het resultaat daar wel op neer.

Compagnie en kerk hebben beide, en met volledig succes, de assimilatie van de vreemdelingen ter hand genomen. De eerste, door hen onder de oude ingezetenen verspreid te doen wonen, en door de schoolmeesters op te dragen, ,die kinderen van fransche ouders gebooren voor alle de Nederduijtsche tale te doen leeren lezen en verstaen, om door dat middel onze natie te meer te werden ingelijft." 7) De maatregel en de motivering doen modern aan. Maar wat zat er achter? We weten het van Goeverneur van der Stel, die met de uitvoering van deze politiek belast was. Ook hij wenste de vluchtelingen "met onzen landaard te vermengen," doch met het doel, „dat d'een van den anderen 't gunt van ieders kenms is mag leeren-en soo doende den landbouw beter voort setten." 8) Als altijd gaat 't economisch motief voorop! En onmiddellijk volgt daarop het staatkundig: van der Stel was immers beducht, dat deze Zuiderlingen, wanneer men ze bijeen liet, een roerig element in de bevolking zouden vormen, en bovendien vreesde hij, in deze tijd van de Negenjarige oorlog, dat bij een eventuele Franse aanval het bloed zou gaan spreken en op de trouw van de voormalige onderdanen van Lodewijk XIV niet onvoorwaardelijk kon worden staat gemaakt.

De kerk daarentegen werd gedreven door de belangen van zielszorg en rechtzinnigheid. De kerkraad van Drakesteijn zou, vertrouwde de classis Amsterdam waaronder hij ressorteerde, „de menschen van die natie in den ommegang lokken; der Nederduijtsche tale en schriftuurlijke wijse van de Godgeleertheyt te behandelen allengskens meer gewoon maken, en dus de traagheid en ijverloosheid van velen omtrent den openbaaren Godsdienst overwinnen." 9) Zodra het maar enigszins doenlijk was, heeft zij ook aan het preken in het Frans om dezelfde reden een eind gemaakt, niettegenstaande in het moederland zelf de Franse diensten in de Waalse kerken steeds in zwang waren gebleven.

Maar wat, zuiver nationaal-cultureel bezien, vooral op de credietzijde van de kerk moet worden geboekt, is dit: meer dan enige andere binding, hetzij die van taal- of van volksgemeenschap, vormde de band aan haar het stevigste fundament van eenheid, zowel tussen de nederzetters

7) Brief van de Kamer van Amsterdam, 17 Dec. 1690, bij C. Graham Botha. Die Kaapse Hugenote (1939), blz. 169.

8) t.a.p.. blz. 170 .

9) C. Spoelstra. Bouwstoffen voor de geschiedenis der Nederduitsche-Gereformeerde Kerken in Zuid-Afrika, dl. II (1907), blz. 15. 
onderling als tussen hen en het moederland. Lange tijd is immers de bevolking kerkelijk ėén geweest. In patria werd daar bij de uitzending van "Coloniers" rekening mee gehouden. Zij konden alleen vertrekken met het getuigenis, dat zij waren van de Gereformeerde religie, en m.n. „papisten” werden zonder meer geweerd. 10) De betekenis daarvan kan niet licht overschat worden. Zo bleef immers het verband gehandhaafd met de vaderlandse kerk, van welke men advies, leiding en predikanten ontving. Sterker nog dan in de aan dissenters rijke Republiek kon daardoor de Gereformeerde Kerk in de Kaapse maatschappij het openbare leven onder haar beslag leggen. Meer wellicht dan enige andere instantie heeft zij er voor gezorgd, dat Nederlandse zeden en gebruiken daar bewaard bleven. Maar bovendien was in die tijd, toen geloofsverwantschap nog vaak boven nationale verscheidenheid prevaleerde, deze Hollandsgeoriënteerde kerkelijke gemeenschap in staat, een krachtig saambindende factor te vormen voor de Zuidafrikaanse natie-in-wording, met haar inkomelingen van verschillende volksaard. Pas toen de confessionele eenheid niet langer bewaard kon blijven, werd het nodig er op toe te zien, dat de nu opkomende kerkelijke tegenstellingen niet verscherpt zouden worden door onderscheid in nationaliteit. Vandaar de wens van de gecombineerde kerkvergadering aan de Kaap, dat uit het vaderland, indien onverhoopt de Luthersen toestemming mochten verkrijgen tot stichting van een eigen kerk, hun dan ,geen Deen ofte buytenlandts praedikant, maar een goed Nederlander gezonden werdt, opdat dus de vreede tusschen ons ende de Broederen des te beeter mag standt grijpen." 11)

Maar opnieuw moet worden vastgesteld: deze invloed van de kerk ter bevordering van het culturele en nationale leven was niet meer dan een onopzettelijk uitvloeisel van de vervulling van haar eigenlijke taak.

Van Riebeeck en zijn mannen zijn naar Zuid-Afrika gegaan om handelsvoordeel te behalen, een overigens allerminst onwaardig motief. $\mathrm{Zij}$ hebben er, al kwamen ze daar niet voor, het Christendom en de Christelijke Nederlandse beschaving gebracht. De beoogde materiële winst is van tijdelike aard geweest. Het geestelijk gewin heeft de eeuwen verduurd. Wonderlijk zijn inderdaad de wegen der Voorzienigheid!

10) Pieter van Dam. Beschrijvinge van de Oostindische Compagnie, uitg. door Dr. F. W. Stapel, 2e Boek, dl. III (1939), blz. 502.

11) Spoelstra, a.w., dl. I, blz. 271 (18 April 1757). 